\title{
Rifampin pharmacokinetics in children, with and without human immunodeficiency virus infection, hospitalized for the management of severe forms of tuberculosis Hendrik Simon Schaaf*1, Marianne Willemse ${ }^{1}$, Karien Cilliers ${ }^{2}$, Demetre Labadarios 2,6, Johannes Stephanus Maritz ${ }^{3}$, Gregory D Hussey ${ }^{4}$, Helen McIlleron ${ }^{5}$, Peter Smith ${ }^{5}$ and Peter Roderick Donald ${ }^{1,3}$
}

\begin{abstract}
Address: ${ }^{1}$ Department of Paediatrics and Child Health, Faculty of Health Sciences, Stellenbosch University and Tygerberg Children's Hospital, PO Box 19063, Tygerberg 7505, South Africa, ${ }^{2}$ Department of Human Nutrition, Faculty of Health Sciences, Stellenbosch University, Tygerberg 7505, South Africa, ${ }^{3}$ Division of Molecular Biology and Human Genetics and the Medical Research Council Centre for Molecular and Cellular Biology, Department of Science and Technology/National Research Foundation Centre of Excellence for Biomedical Tuberculosis Research, Faculty of Health Sciences, Stellenbosch University, PO Box 19063, Tygerberg 7505, South Africa, ${ }^{4}$ Institute of Infectious Diseases and Molecular Medicine, University of Cape Town, Rondebosch 7701, South Africa, ${ }^{5}$ Division of Clinical Pharmacology, University of Cape Town, Rondebosch 7701, South Africa and ${ }^{6}$ Knowledge Systems, Human Sciences Research Council, Private Bag X9182, Cape Town 8000, South Africa
\end{abstract}

Email:Hendrik Simon Schaaf* - hss@sun.ac.za; Marianne Willemse - mwillemse@cybersmart.co.za; Karien Cilliers - karien.cilliers@adept.co.za; Demetre Labadarios - DLabadarios@hsrc.ac.za; Johannes Stephanus Maritz - mwstefan@mweb.co.za;

Gregory D Hussey - gregory.hussey@uct.ac.za; Helen McIlleron - Helen.McIlleron@uct.ac.za; Peter Smith - Peter.Smith@uct.ac.za; Peter Roderick Donald - prd@sun.ac.za

* Corresponding author

Published: 22 April 2009

Received: 27 March 2009

BMC Medicine 2009, 7:19 doi:10.1186/1741-7015-7-19

Accepted: 22 April 2009

This article is available from: http://www.biomedcentral.com/1741-7015/7/19

(C) 2009 Schaaf et al; licensee BioMed Central Ltd.

This is an Open Access article distributed under the terms of the Creative Commons Attribution License (http://creativecommons.org/licenses/by/2.0), which permits unrestricted use, distribution, and reproduction in any medium, provided the original work is properly cited.

\begin{abstract}
Background: Rifampin is a key drug in antituberculosis chemotherapy because it rapidly kills the majority of bacilli in tuberculosis lesions, prevents relapse and thus enables 6-month short-course chemotherapy. Little is known about the pharmacokinetics of rifampin in children. The objective of this study was to evaluate the pharmacokinetics of rifampin in children with tuberculosis, both human immunodeficiency virus type-I-infected and human immunodeficiency virus-uninfected.
\end{abstract}

Methods: Fifty-four children, 21 human immunodeficiency virus-infected and 33 human immunodeficiency virus-uninfected, mean ages 3.73 and 4.05 years $(P=0.68)$, respectively, admitted to a tuberculosis hospital in Cape Town, South Africa with severe forms of tuberculosis were studied approximately I month and 4 months after commencing antituberculosis treatment. Blood specimens for analysis were drawn in the morning, 45 minutes, I.5, 3.0, 4.0 and 6.0 hours after dosing. Rifampin concentrations were determined by liquid chromatography tandem mass spectrometry. For two sample comparisons of means, the Welch version of the t-test was used; associations between variables were examined by Pearson correlation and by multiple linear regression.

Results: The children received a mean rifampin dosage of $9.61 \mathrm{mg} / \mathrm{kg}$ (6.47 to 15.58 ) body weight at I month and $9.63 \mathrm{mg} / \mathrm{kg}$ (4.63 to 17.8) at 4 months after commencing treatment administered as part of a fixed-dose formulation designed for paediatric use. The mean rifampin area under the curve 0 to 6 hours after dosing was 14.9 and $18.1 \mu \mathrm{g} / \mathrm{hour} / \mathrm{ml}(P=0.25)$ I month after starting treatment in human immunodeficiency virus-infected and human immunodeficiency virus- 
uninfected children, respectively, and 16.52 and $17.94 \mu \mathrm{g} / \mathrm{hour} / \mathrm{ml}(P=0.59)$ after 4 months of treatment. The mean calculated 2 -hour rifampin concentrations in these human immunodeficiency virus-infected and human immunodeficiency virus-uninfected children were 3.9 and $4.8 \mu \mathrm{g} / \mathrm{ml}(P=$ $0.20)$ at I month after the start of treatment and 4.0 and $4.6 \mu \mathrm{g} / \mathrm{ml}(P=0.33)$ after 4 months of treatment. These values are considerably less than the suggested lower limit for 2-hour rifampin concentrations in adults of $8.0 \mu \mathrm{g} / \mathrm{ml}$ and even $4 \mu \mathrm{g} / \mathrm{ml}$

Conclusion: Both human immunodeficiency virus-infected and human immunodeficiency virusuninfected children with tuberculosis have very low rifampin serum concentrations after receiving standard rifampin dosages similar to those used in adults. Pharmacokinetic studies of higher dosages of rifampin are urgently needed in children to assist in placing the dosage of rifampin used in childhood on a more scientific foundation.

\section{Background}

Rifampin (RMP) is a key drug in modern antituberculosis chemotherapy by virtue of its unique ability to rapidly kill the majority of bacilli in tuberculosis lesions, prevent relapse and thus enable 6-month short-course chemotherapy. Inadequate absorption of RMP has been documented under different circumstances in a number of studies of adult tuberculosis patients; it has been found in human immunodeficiency virus (HIV) type-1-uninfected patients [1,2], amongst HIV-infected patients [3-5], and in some studies amongst both HIV-infected and HIV-uninfected patients [6-8]. In another recent study, although low RMP plasma concentrations were found in both HIV-infected and HIV-uninfected patients, HIV-infected patients were at greater risk for poor RMP absorption [9]. Others evaluating smaller numbers of patients have found adequate absorption amongst HIV-infected patients [10,11]. It has also been remarked that there is considerable intra-individual variation in RMP pharmacokinetics.

There is very little available information describing RMP pharmacokinetics in children and there is no information regarding the possible influence of HIV infection on RMP pharmacokinetics in children. This paper describes the pharmacokinetics of RMP in a group of children from the Western Cape Province of South Africa, both HIV-infected and HIV-uninfected, admitted to a tuberculosis referral hospital with severe forms of childhood tuberculosis.

\section{Methods \\ Setting}

The Brooklyn Hospital for Chest Diseases (BHCD) is a referral hospital for severe forms of tuberculosis occurring within the city of Cape Town. During the period January 2004 to December 2006 children aged 3 months to 13 years admitted to BHCD were eligible for enrolment in a study of the pharmacokinetics of antituberculosis agents. Admission to BHCD occurred approximately 1 month after commencement of treatment at the referring hospital.

\section{Diagnosis of tuberculosis}

The diagnosis of tuberculosis was confirmed by culture of gastric aspirate, or sputum in older children, together with culture of cerebrospinal fluid in suspected cases of tuberculous meningitis; these investigations were usually carried out at referring hospitals before admission to BHCD. Mantoux testing was with tuberculin RT23 and induration was measured in the transverse diameter of the forearm after 48 to 72 hours. Induration of at least $10 \mathrm{~mm}$ was taken as indicative of Mycobacterium tuberculosis infection in HIV-uninfected children, but at least $5 \mathrm{~mm}$ in those HIV-infected. All parents or caregivers were questioned as to the presence in the child's household within the last year of cases of sputum-microscopy, smear-positive pulmonary tuberculosis. Chest radiographs were considered indicative of pulmonary tuberculosis in the presence of unequivocal mediastinal adenopathy; a diagnosis of tuberculous meningitis was accepted in the presence of hydrocephalus and basal enhancement seen on cranial computerised tomography, accompanied by appropriate cerebrospinal fluid changes. Two or more of the above clinical criteria were required to establish a diagnosis of probable tuberculosis.

\section{Treatment}

Treatment for all forms of tuberculosis was with fixeddose combinations (FDC) formulated for paediatric use; each tablet used during the intensive treatment phase contained RMP $60 \mathrm{mg}$, isoniazid (INH) $30 \mathrm{mg}$ and pyrazinamide $150 \mathrm{mg}$ (Rimcure ${ }^{\mathrm{R}}$ ) and during the continuation phase RMP $60 \mathrm{mg}$ and INH $30 \mathrm{mg}$ (Rimactazid ${ }^{\mathrm{R}}$ ). One tablet was used for every $5 \mathrm{~kg}$ increase in body weight. Rimcure $^{\mathrm{R}}$ and Rimactazid ${ }^{\mathrm{R}}$ were supplied by Sandoz SA Pty Ltd Spartan, South Africa; these formulations are approved by the South African Medicines Control Council and were dispensed by the BHCD pharmacy. During the intensive phase ethambutol was added when the use of four drugs was considered advisable. Tuberculous meningitis was managed with the same FDC, but with ethionamide added, all given for 6 months. All tuberculosis 
treatment was given daily and observed by hospital nursing staff. On the day of a pharmacokinetic study, drug administration was undertaken by study personnel. All of the children were supplemented with a multivitamin syrup. This supplied pyridoxine $0.5 \mathrm{mg}$ for children aged 0 to 4 years, but $1 \mathrm{mg}$ for those $>5$ years; each $5 \mathrm{ml}$ contained vitamin A 2300 IU, vitamin D 200 IU, vitamin B1 $1 \mathrm{mg}$, vitamin B2 $1.2 \mathrm{mg}$, nicotinamide $5 \mathrm{mg}$, vitamin $\mathrm{C}$ $35 \mathrm{mg}$ and vitamin B12 $0.0025 \mathrm{mg}$. All HIV-infected children received trimethoprim-sulphamethoxazole. Antiretroviral treatment consisted of two nucleoside reverse transcriptase inhibitors and ritonavir in children less than 3 years of age (Kaletra ${ }^{\mathrm{R}}$ was not yet available), and ritonavir was replaced by efavirenz in children older than 3 years.

\section{Pharmacokinetic study}

RMP plasma concentrations were measured within a week of admission to BHCD (approximately 1 month after initial admission to the referral hospital) and again 4 months after commencing treatment to evaluate the possible influence of nutrition, disease state and intra-individual variation on RMP pharmacokinetics. The children were nil per mouth from midnight and an intravenous catheter was inserted after the application of a local anaesthetic jelly (Ametop ${ }^{\mathrm{R}}$ ). Medication was administered by study personnel. Blood specimens were taken at $45 \mathrm{~min}-$ utes, 1.5, 3.0, 4.0 and 6.0 hours after dosing, immediately placed on ice and centrifuged within 30 minutes. A plasma sample of $1 \mathrm{ml}$ was stored in polypropylene tubes at $-80^{\circ} \mathrm{C}$ and protected from light until analysed. The specimens were analysed for RMP by liquid chromatography tandem mass spectrometry as described previously [12]; the limit of quantification was $0.1 \mu \mathrm{g} / \mathrm{ml}$. The reference standard for RMP was purchased from Sigma (StLouis, MO, USA).

\section{Nutritional and clinical evaluation}

Body mass and height, or length in those less than 2 years of age, and mid-upper arm circumference were measured by standard anthropometric methods by a qualified dietician and the mean of three readings taken $[13,14]$. Serum bilirubin and alanine transferase (ALT) were determined at the time of each pharmacokinetic evaluation.

The presence of abdominal nodes was evaluated by abdominal ultrasound at enrolment in all children.

Plasma C-reactive protein (CRP) was determined by an immunoradiometric assay at 1 and 4 months of treatment in all children [15].

The children's HIV status was determined by enzymelinked immunosorbent assay and positive results confirmed by a second assay, or by polymerase chain reaction in children younger than 18 months. Counselling of the parents or legal guardians preceded HIV-testing and written informed consent was obtained.

\section{Statistics}

For two sample comparisons of means the Welch version of the t-test was used; associations between variables were examined by Pearson correlation and by multiple linear regression. $C_{\max }$ is the observed maximum value for each individual and $T_{\max }$ the time at which $C_{\max }$ was recorded. The area under the curve (AUC) over the period 0 to 6 hours after dosing was calculated by the linear trapezoidal rule. Experience with published reference ranges for RMP plasma concentrations from studies in healthy volunteers and tuberculosis patients have suggested that 2-hour concentrations of less than $8 \mu \mathrm{g} / \mathrm{ml}$ should be regarded as low and values less than $4 \mu \mathrm{g} / \mathrm{ml}$ as very low $[5,8,16]$. The 2 hours after dosing RMP plasma concentrations were thus calculated as $[(2 / 3)(1.5$ hour value+ $(1 / 3)(3.0$ hour value)]. These calculated values were compared with interpolated values obtained from fitting a two-compartment regression model to the data. The correlation coefficients between the two sets of interpolated values were 0.983 and 0.982 at enrolment and at 4 months after treatment commencement, respectively, with negligible bias between the mean values.

The study was approved by the Institutional Review Board of the Faculty of Health Sciences of Stellenbosch University (No. 2003/054/N). All parents or legal guardians gave written informed consent for their children's participation in the study.

\section{Results}

Sixty children, 26 HIV-infected and 34 HIV-uninfected, were enrolled in the study. Four children (all HIVinfected) were transferred back to referring hospitals shortly after enrolment due to complications that could not be managed at BHCD and were not studied further; two children (one each HIV-infected and HIV-uninfected) were discharged from hospital after completion of the first pharmacokinetic study and their data were not included in this analysis. Due to our inability to maintain the intravenous line, single data points were not available for 14 children (usually the 6-hour data point), two data points were missing from two children and three data points from one patient. Pharmacokinetic data were thus available for analysis on enrolment and after 4 months of treatment from 21 HIV-infected children and 33 HIVuninfected children. The period between the start of treatment and admission to BHCD and enrolment in the study at BHCD did not differ between the HIV-infected and HIV-uninfected children: 34.2 days (standard deviation (SD) 21.8) and 38.0 days (SD 19.3), respectively $(P=$ $0.49)$. 
Two HIV-infected children were already receiving antiretroviral treatment at the time of admission to BHCD and a further seven children were commenced on antiretroviral treatment, but this occurred only shortly before the completion of the second pharmacokinetic study.

Demographic, diagnostic and clinical features of the children are summarised in Table 1 . Overall a culture of $M$. tuberculosis was obtained from 28 (51\%) children and in a further three HIV-infected children with negative cultures, acid-fast bacilli were seen on microscopy of gastric aspirates. Only four $(20 \%)$ HIV-infected children had a positive Mantoux test and this was greater than $10 \mathrm{~mm}$ in each case. A majority of children suffered from one or other form of malnutrition; although the proportion of HIVuninfected children suffering from kwashiorkor and with a body mass less than the third percentile for age was sim- ilar to that amongst HIV-infected children, significantly more HIV-infected children were marasmic.

Table 2 summarises certain anthropometric features and CRP concentrations of the children on enrolment (after 1 month of treatment) and after 4 months treatment. At neither assessment did the anthropometric findings differ between the HIV-infected or HIV-uninfected children. At the 4-month assessment the anthropometric parameters showed improvement in both groups of children. On enrolment the mean CRP concentrations were raised in both groups of children, but were significantly higher in the HIV-infected children; by the 4-month assessment the CRP concentrations had declined in both groups, but while those of the HIV-uninfected children had normalised, with the exception of two children, those of the HIVinfected children remained elevated. With regard to liver function evaluation, no child had a raised serum

Table I: Demographic, diagnostic, clinical and radiological features of human immunodeficiency virus (HIV)-infected and HIVuninfected children being treated for tuberculosis.

\begin{tabular}{|c|c|c|c|}
\hline & $\begin{array}{l}\text { Human immunodeficiency virus- } \\
\text { infected } \\
N=21\end{array}$ & $\begin{array}{l}\text { Human immunodeficiency virus- } \\
\text { uninfected } \\
N=33\end{array}$ & $P$ value \\
\hline Age (years) & 3.73 & 4.05 & 0.68 \\
\hline Male sex & $12(57 \%)$ & $16(48 \%)$ & 0.58 \\
\hline $\begin{array}{l}\text { Culture of } M \text {. tuberculosis or acid-fast bacillus smear } \\
\text { seen on microscopy }{ }^{\prime}\end{array}$ & $10(48 \%)$ & $18(60 \%)$ & 0.16 \\
\hline Household tuberculosis contact & $14(67 \%)$ & $23(70 \%)$ & 0.82 \\
\hline \multicolumn{4}{|l|}{ Mantoux test ${ }^{2}$} \\
\hline$\geq 10 \mathrm{~mm}$ & $4(20 \%)$ & $30(91 \%)$ & $<0.001$ \\
\hline$\geq 5 \mathrm{~mm}$ & - & - & \\
\hline \multicolumn{4}{|l|}{ Clinical features } \\
\hline Pulmonary tuberculosis & $18(86 \%)$ & 27 (82\%) & 0.72 \\
\hline Tuberculous meningitis & $7(33 \%)$ & $19(58 \%)$ & 0.16 \\
\hline \multicolumn{4}{|l|}{ Nutritional status } \\
\hline Mass $<3 r d$ percentile for age & $8(38 \%)$ & $13(39 \%)$ & $>0.99$ \\
\hline Kwashiorkor & $6(29 \%)$ & $6(18 \%)$ & 0.50 \\
\hline Marasmus & $8(38 \%)$ & $3(9 \%)$ & 0.014 \\
\hline Marasmic kwashiorkor & $4(19 \%)$ & $3(9 \%)$ & 0.41 \\
\hline \multicolumn{4}{|l|}{ Radiological features } \\
\hline Hilar adenopathy & II (52\%) & $18(55 \%)$ & $>0.99$ \\
\hline Lobar opacification & $9(43 \%)$ & $10(30 \%)$ & 0.39 \\
\hline Micronodular opacification & $5(24 \%)$ & $7(2 \mid \%)$ & $>0.99$ \\
\hline Cavitation & 0 & $6(18 \%)$ & 0.072 \\
\hline Abdominal nodes ${ }^{3}$ & $5(24 \%)$ & $6(18 \%)$ & 0.73 \\
\hline
\end{tabular}

'Culture and microscopy not carried out in three human immunodeficiency virus (HIV)-uninfected children. 2 Mantoux test not read in one HIV-uninfected child.

${ }^{3}$ Abdominal nodes visualised on ultrasound. 
Table 2: Anthropometrical evaluation and serum C-reactive protein levels in human immunodeficiency virus (HIV)-infected and HIVuninfected children being treated for tuberculosis on enrolment after I month and $\mathbf{4}$ months of treatment.

\begin{tabular}{|c|c|c|c|c|c|c|}
\hline & $\begin{array}{l}\text { Human } \\
\text { immunodeficiency } \\
\text { virus-infected } \\
N=21 \text { (SD) }\end{array}$ & $\begin{array}{l}\text { Human } \\
\text { immunodeficiency } \\
\text { virus- } \\
\text { uninfected } \\
N=33 \\
\text { (SD) }\end{array}$ & $P$ value & $\begin{array}{l}\text { Human } \\
\text { immunodeficiency } \\
\text { virus-infected } \\
N=21 \\
\text { (SD) }\end{array}$ & $\begin{array}{l}\text { Human } \\
\text { immunodeficiency } \\
\text { virus-uninfected } \\
N=33 \\
\text { (SD) }\end{array}$ & $P$ value \\
\hline & On enrolment & & & $\begin{array}{l}\text { After } 4 \text { months of } \\
\text { treatment }\end{array}$ & & \\
\hline Weight (kg) & $\begin{array}{l}12.26 \\
(5.18)\end{array}$ & $\begin{array}{l}13.97 \\
(6.94)\end{array}$ & 0.30 & $\begin{array}{l}13.06 \\
(5.33)\end{array}$ & $\begin{array}{l}15.04 \\
(8.01)\end{array}$ & 0.29 \\
\hline Length/height $(\mathrm{cm})$ & $\begin{array}{l}86.80 \\
(16.22)\end{array}$ & $\begin{array}{l}91.53 \\
(20.85)\end{array}$ & 0.36 & $\begin{array}{l}89.26 \\
(16.39)\end{array}$ & $\begin{array}{l}93.67 \\
(20.37)\end{array}$ & 0.40 \\
\hline Body mass index & $\begin{array}{l}15.59 \\
(1.62)\end{array}$ & $\begin{array}{l}15.71 \\
(1.91)\end{array}$ & 0.80 & $\begin{array}{l}15.74 \\
(1.53)\end{array}$ & $\begin{array}{l}16.05 \\
(1.71)\end{array}$ & 0.51 \\
\hline $\begin{array}{l}\text { Mid-upper arm } \\
\text { circumference }(\mathrm{cm})\end{array}$ & $\begin{array}{l}14.28 \\
(2.16)\end{array}$ & $\begin{array}{l}15.07 \\
(2.39)\end{array}$ & 0.21 & $\begin{array}{l}14.44 \\
(2.22)\end{array}$ & $\begin{array}{l}15.46 \\
(2.63)\end{array}$ & 0.16 \\
\hline $\begin{array}{l}\text { Serum C-reactive } \\
\text { protein } \\
\text { (mg/litre) }\end{array}$ & $\begin{array}{l}39.97 \\
(54.55)\end{array}$ & $\begin{array}{l}13.42 \\
(17.96)\end{array}$ & 0.06 & $\begin{array}{l}22.47 \\
(22.28)\end{array}$ & $\begin{array}{l}4.15 \\
(4.96)\end{array}$ & 0.002 \\
\hline
\end{tabular}

SD, standard deviation.

bilirubin; at 1 month after commencement of treatment serum ALT was raised (more than $37 \mathrm{U} /$ litre) in three $(14.3 \%)$ HIV-infected children and was more than three times the normal level in two children $(9.5 \%)$, while amongst the HIV-uninfected children, four $(12.1 \%)$ children had an increased ALT and this was more than three times the normal level in two (6.1\%) At 4 months ALT was increased in $6(28.6 \%)$ HIV-infected children, but more than three times the normal in only two $(9.5 \%)$ and amongst the HIV-uninfected ALT was raised in four chil- dren $(12.1 \%)$ and in none was the value more than three times the normal level.

The children received a mean RMP dosage of $9.61 \mathrm{mg} / \mathrm{kg}$ (range 6.47 to 15.58 , SD 1.69) for the pharmacokinetic study on enrolment and $9.63 \mathrm{mg} / \mathrm{kg}$ (range 4.63 to 17.8 , SD 2.26) during the 4-month study $(P=0.93)$. On enrolment one HIV-uninfected child received a RMP dose of less than $8 \mathrm{mg} / \mathrm{kg}$ and two HIV-uninfected children and one HIV-infected child a dose of more than $12 \mathrm{mg} / \mathrm{kg}$; during the 4-month assessment two HIV-uninfected chil-

Table 3: Mean rifampin plasma concentrations $(\mu \mathrm{g} / \mathrm{ml})$ in human immunodeficiency virus (HIV)-infected and HIV-uninfected children being treated for tuberculosis on enrolment after I-month and 4-months of treatment.

\begin{tabular}{|c|c|c|c|c|c|c|c|c|c|c|}
\hline \multirow{2}{*}{$\begin{array}{l}\text { Time after } \\
\text { dosing (hours) }\end{array}$} & \multicolumn{5}{|c|}{ Enrolment (SD) } & \multicolumn{5}{|c|}{4 months (SD) } \\
\hline & $N$ & $\begin{array}{l}\text { Human } \\
\text { immunodeficiency } \\
\text { virus-infected }\end{array}$ & $N$ & $\begin{array}{l}\text { Human } \\
\text { immunodeficiency } \\
\text { virus-uninfected }\end{array}$ & $\begin{array}{l}P \\
\text { value }\end{array}$ & $N$ & $\begin{array}{l}\text { Human } \\
\text { immunodeficiency } \\
\text { virus-infected }\end{array}$ & $N$ & HIV-uninfected & $P$ value \\
\hline 0.75 & 21 & $2.35(2.54)$ & 32 & $4.02(5.10)$ & 0.12 & 20 & $3.11(3.45)$ & 33 & $3.84(3.72)$ & 0.47 \\
\hline 1.5 & 21 & $4.26(1.96)$ & 33 & $5.63(4.07)$ & 0.10 & 21 & $4.28(2.66)$ & 33 & $5.31(3.01)$ & 0.19 \\
\hline 2.01 & 21 & $3.90(1.67)$ & 33 & $5.07(3.59)$ & 0.11 & 21 & $4.00(2.04)$ & 32 & $4.6 I(2.43)$ & 0.33 \\
\hline 3.0 & 20 & $3.01(1.96)$ & 33 & $3.93(3.50)$ & 0.22 & 21 & $3.43(2.83)$ & 32 & $3.58(2.42)$ & 0.84 \\
\hline 4.0 & 21 & $2.22(1.67)$ & 32 & $3.17(4.54)$ & 0.29 & 20 & $2.60(1.74)$ & 32 & $2.4 I(1.94)$ & 0.72 \\
\hline 6.0 & 16 & $1.12(1.41)$ & 28 & $1.95(4.45)$ & 0.37 & 17 & $1.09(0.88)$ & 30 & $0.88(0.96)$ & 0.47 \\
\hline$C_{\max }(\mu g / m l)$ & 21 & $4.91(2.03)$ & 33 & $6.92(5.88)$ & 0.08 & 21 & $5.67(3.30)$ & 33 & $6.26(3.4 I)$ & 0.53 \\
\hline$T_{\max }$ (hour) & 21 & $1.80(0.87)$ & 33 & $1.67(0.93)$ & 0.62 & 21 & $2.17(1.30)$ & 33 & $1.71(0.88)$ & 0.17 \\
\hline $\begin{array}{l}\mathrm{AUC}_{0-6}(\mu \mathrm{g} / \text { hourl } \\
\mathrm{ml})\end{array}$ & 21 & $14.88(7.43)$ & 32 & $18.07(12.52)$ & 0.25 & 21 & $16.52(8.84)$ & 33 & $17.94(10.36)$ & 0.59 \\
\hline
\end{tabular}

IThe 2-hour plasma concentrations are calculated as $[(2 / 3)(1.5$ hour value $+(1 / 3)(3.0$ hour value $)]$. $C_{\max }=$ observed maximum value for each individual; $T_{\max }=$ the time at which $C_{\max }$ was recorded.

$A \cup C$, area under the curve. 
dren received a dose of less than $8 \mathrm{mg} / \mathrm{kg}$ and three HIVuninfected children a dose of more than $12 \mathrm{mg} / \mathrm{kg}$.

Table 3 gives the RMP plasma concentrations determined at 45 minutes, 1.5 hours, 3.0 hours, 4.0 hours and 6.0 hours and those calculated for 2 hours after dosing 1 month and 4 months after commencing treatment; Figure 1 illustrates these serum concentrations in HIV-infected and HIV-uninfected children. The mean $\mathrm{AUC}_{0-6}$ on enrolment was 14.88 and $18.07 \mu \mathrm{g} /$ hour $/ \mathrm{ml}(P=0.25)$ in HIVinfected and HIV-uninfected children, respectively, and after 4 months of treatment 16.52 and $17.94 \mu \mathrm{g} /$ hour $/ \mathrm{ml}$ $(P=0.59)$. While a majority of children have a consistent $\mathrm{AUC}_{0-6}$ on both occasions there was considerable interindividual and intra-individual variation evident. Thus, the $\mathrm{AUC}_{0-6}$ of all 55 children was 16.81 (SD 10.82) on enrolment and 17.39 (SD 9.74) after 4 months of treatment, but the correlation of the $\mathrm{AUC}_{0-6}$ on enrolment with that after 4 months of treatment was low $(r=0.313$, $P=0.022)$. There was no correlation between $\mathrm{AUC}_{0-6}$ and body mass index either at enrolment (one outlier excluded) or at 4 months of treatment $(r=0.109, P=$ $0.444 ; r=0.014, P=0.920$, respectively).

The mean calculated 2-hour RMP concentrations of the HIV-infected and HIV-uninfected children on enrolment were 3.90 and $4.78 \mu \mathrm{g} / \mathrm{ml}$, respectively; although these mean values did not differ significantly $(P=0.20)$, the SD of the HIV-infected group (3.25) was significantly greater $(P=0.002)$ than that of the HIV-uninfected group (1.67). At the 4-month assessment the mean calculated 2-hour RMP plasma concentrations of the HIV-infected and HIVuninfected groups were $3.96 \mu \mathrm{g} / \mathrm{ml}$ (SD 2.04) and 4.61 $\mu \mathrm{g} / \mathrm{ml}$ (SD 2.43), respectively, and neither the means $(P=$ $0.33)$ nor the SD $(P=0.40)$ differed significantly. At the first pharmacokinetic evaluation on enrolment only five (9\%) children had calculated 2-hour concentrations greater than $8 \mu \mathrm{g} / \mathrm{ml}$, while 25 (47\%) had values less than $4 \mu \mathrm{g} / \mathrm{ml}$; although more HIV-infected than HIV-uninfected children had such low values $(57 \%$ and $41 \%$, respectively), the difference was not significant $(P=0.37)$. At 4 months after treatment commencement three children $(6 \%)$ had 2-hour RMP concentrations greater than 8 $\mu \mathrm{g} / \mathrm{ml}$ and 25 (43\%) values less than $4 \mu \mathrm{g} / \mathrm{ml}$; the proportions of HIV-infected and uninfected children with such very low values were $39 \%$ and $43 \%$, respectively $(P=$ 0.83 ). There was no relationship between HIV staging and RMP plasma concentrations either on enrolment or after 4 months of treatment.

In children with and without abdominal nodes visible on ultrasound examination on enrolment the mean $C_{\max }$ concentrations were $5.3 \mu \mathrm{g} / \mathrm{ml}$ (SD 5.2) and $6.3 \mu \mathrm{g} / \mathrm{ml}$ (SD 3.4), respectively, and at 4 months after commence- ment of treatment $5.3 \mu \mathrm{g} / \mathrm{ml}$ (SD 2.9) and $6.2 \mu \mathrm{g} / \mathrm{ml}$ (3.5), and neither of these differences were significant.

The study was not intended to compare the outcome of treatment, but on discharge from BHCD all children who had a positive culture of $M$. tuberculosis on commencement of treatment were culture-negative. We are aware of one HIV-infected child who has subsequently relapsed, but the children were not specifically followed up to detect relapse. Of the $21 \mathrm{HIV}$-infected children three $(14.3 \%)$ had not gained in weight compared to three $(8.8 \%)$ of the 34 HIV-uninfected children. Sixteen HIVinfected children had an abnormal chest radiograph on study commencement and by the time of discharge six children (37.5\%) showed some clearing, five (31.3\%) had cleared, but five (31.3\%) remained unchanged. Amongst the 34 HIV-uninfected children, 27 initially had chest radiographic abnormalities and of these 15 (55.6\%) had improved and 12 (44.4\%) had cleared. No association was shown between these features and any aspect of RMP pharmacokinetics.

\section{Discussion}

This study has documented very low serum RMP concentrations in children, of which the great majority received the often recommended standard dosage of 8 to $12 \mathrm{mg} / \mathrm{kg}$ body weight. Although there was a trend for lower concentrations in HIV-infected children on the first evaluation 1 month after commencing treatment this was not significant and the 4-month evaluation provided no evidence of differences between the HIV-infected and HIVuninfected children. Early studies of RMP pharmacokinetics in children under 18 months of age, conducted amongst children not established on RMP, reported an elimination rate similar to that in adults, but a volume of distribution twice that of adults; RMP absorption was noted to be 'erratic and unpredictable' [17]. In comparison to adults young children receiving a RMP dosage of 10 $\mathrm{mg} / \mathrm{kg}$ appeared to reach considerably lower concentrations of RMP [18]. The relatively low plasma concentrations of RMP reached by children were also evident in other studies and amongst children not established on RMP and receiving a dosage of 10 to $12 \mathrm{mg} / \mathrm{kg}$ peak concentrations of 3 to $9 \mu \mathrm{g} / \mathrm{ml}$ were found [18-22]; it should be noted that the highest values derive from a study during which RMP was administered in a suspension [21], peak concentrations amongst children established on RMP ranged from approximately 3 to $5 \mu \mathrm{g} / \mathrm{ml}$ (see [2325]). On the basis of their findings Hussels et al. [20] considered that children under 6 years of age should receive a RMP dose of $15 \mathrm{mg} / \mathrm{kg}$ body weight and older children 10 $\mathrm{mg} / \mathrm{kg}$.

Comparison of our results with those from adult studies is difficult due to considerable variation in how pharma- 
(A) Enrollment

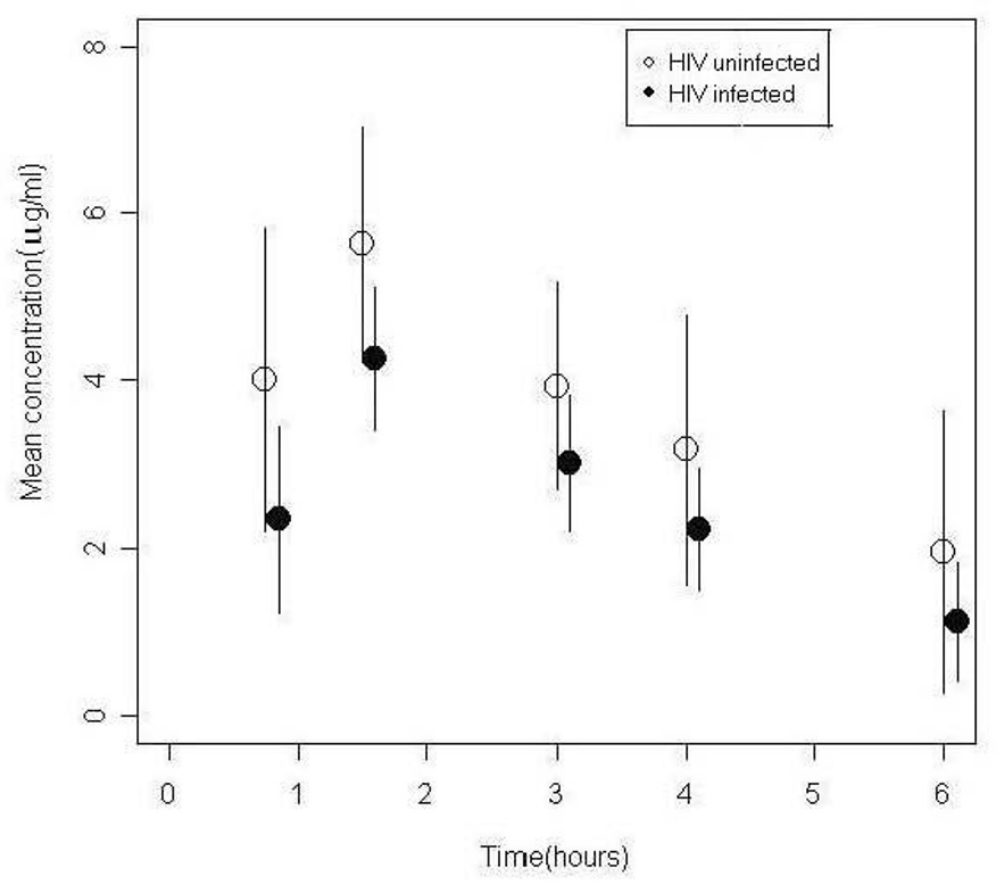

(B) 4 months

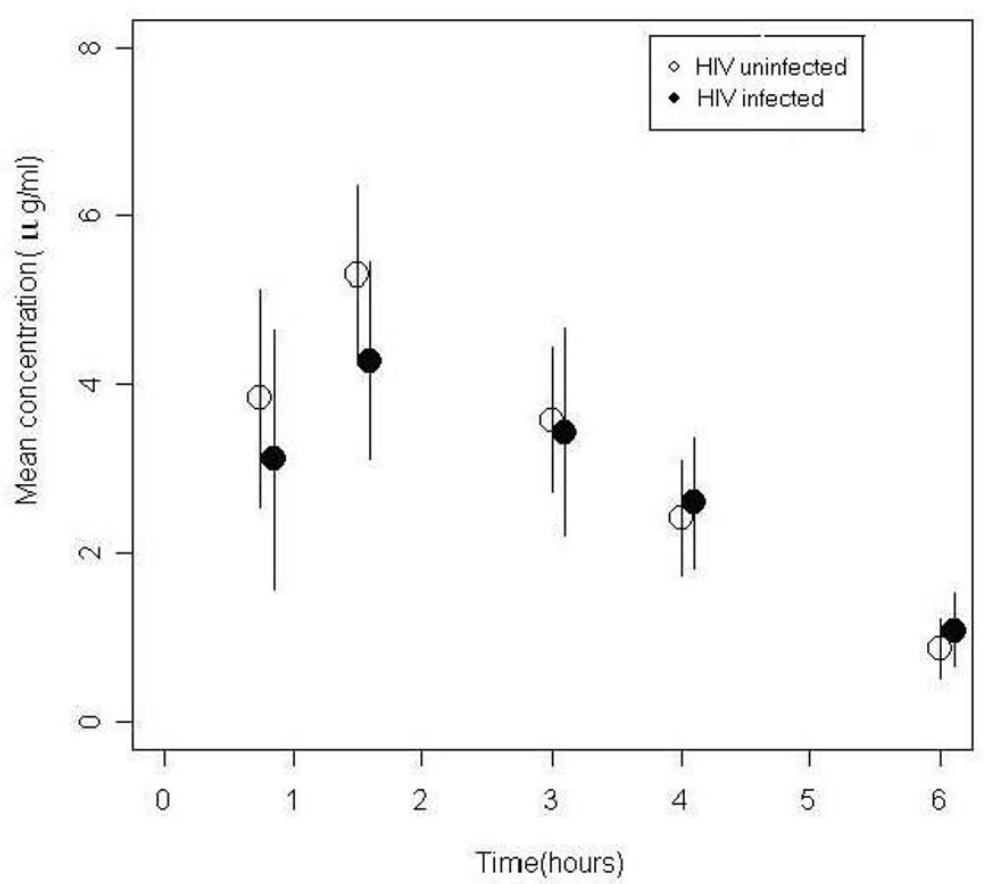

Figure I

Rifampin plasma concentrations $(\mu \mathrm{g} / \mathrm{ml})$ in human immunodeficiency virus (HIV)-infected and HIV-uninfected children being treated for tuberculosis determined on enrolment (A) and after 4 months of treatment (B). 
cokinetic data are presented and in what detail; thus the AUC may be presented calculated over 0 to 6,0 to 12 or 0 to 8 hours. Considerable experience in healthy volunteers and tuberculosis patients has led to the suggestion that RMP concentrations of less than $8 \mu \mathrm{g} / \mathrm{ml} 2$ hours after dosing should be regarded as low and values less than 4 $\mu \mathrm{g} / \mathrm{ml}$ as very low and frequent reference is made in the literature to these values $[5,8,16]$. To enable us to compare our results with these values we calculated the 2-hour RMP serum concentrations in our patients; even allowing for the introduction of a degree of inaccuracy it is clear that, both HIV-infected and HIV-uninfected children, the great majority of whom received the often recommended standard RMP dosages of 8 to $12 \mathrm{mg} / \mathrm{kg}$ body weight $[26,27]$, have very low RMP serum concentrations. Close to half the calculated 2-hour concentrations were less than $4.0 \mu \mathrm{g} / \mathrm{ml}$. This is true of the calculated 2-hour values at both enrolment and after 4 months of treatment. By 4 months the nutritional condition of many of the HIVuninfected children had improved significantly, but their RMP plasma concentrations remained low, so that poor nutrition cannot fully explain this finding. Equally, although both groups of children had evidence of an acute inflammatory response on enrolment, as indicated by elevated serum CRP concentrations, by 4 months after treatment initiation, although there was continued evidence of an acute inflammatory response in the HIVinfected children, all except two of the HIV-uninfected children had normal CRP values.

Two previous studies amongst adult African tuberculosis patients from Kenya and Botswana reported low RMP concentrations similar to those found in our children and also no difference between HIV-infected and HIV-uninfected patients $[6,8]$. However, another study from Cape Town reported low RMP plasma concentrations from 88 adult tuberculosis patients with a median 2-hour plasma concentration of $4.4 \mu \mathrm{g} / \mathrm{ml}$, and found HIV infection to be associated with a $39 \%$ reduction in RMP concentrations with $22 \%$ of 2 -hour values less than $4 \mu \mathrm{g} / \mathrm{ml}$ (see [9]).

In other fields of medicine, such as oncology, it is common practice to determine the dose of an agent for children by reference to body surface area or by making use of percentage of the adult dose as determined, directly or indirectly, from body surface area [28]. Alternatively weight-based bands can be constructed that provide a satisfactory approximation to the use of body surface area and such an approach has been suggested for certain antiretroviral drugs to be administered under programme conditions [29]. Nonetheless recommendations for the dose of RMP for children by the World Health Organization [26,27] and several other bodies make use of the same milligram per kilogram body weight dosage as is recommended for adults. Using a percentage of the adult dose reckoned according to an approximation of body surface area [28] in an hypothetical $10 \mathrm{~kg}$ child leads to a RMP dose of $162 \mathrm{mg}$; if this is then reconverted to a milligram per kilogram dose this would be $16 \mathrm{mg} / \mathrm{kg}$ compared with a RMP dosage of $100 \mathrm{mg}$ calculated according to a flat-rate of $10 \mathrm{mg} / \mathrm{kg}$; it is of interest that the dosage of RMP recommended for use in children in the USA is 15 $\mathrm{mg} / \mathrm{kg}$ with a range of 10 to $20 \mathrm{mg} / \mathrm{kg}$ body weight [30].

Do the differences in exposure to lower serum concentrations of RMP (and other antituberculosis agents) that arise from using the same milligram per kilogram body weight dose in children as in adults matter? On the one hand there are a number of studies documenting a satisfactory response of children with tuberculosis to regimens of drugs used in the currently recommended dosages and several recent studies have suggested a lack of any relationship between RMP serum concentrations and sputum culture-conversion in adults [31,32]. On the other hand, it is also becoming apparent that, in the era of HIV/ acquired immune deficiency syndrome, any reduction in the dose of antituberculosis agents reflected by frequency and length of treatment, particularly in more severe forms of pulmonary tuberculosis may be associated with an increased risk of relapse [33-36]. In immunocompetent patients a RMP $600 \mathrm{mg}$ dosage, associated with INH, led to more rapid sputum sterilisation of adult pulmonary tuberculosis patients than a dosage of $450 \mathrm{mg}$ (see [37]); Buniva et al. [38], after extensive experience with the development of RMP, stated that $T_{\text {max }}$ was usually reached at between 1.5 and 2 hours in human volunteers and that the mean $C_{\max }$ in 95 individuals after dosages of $600 \mathrm{mg}$ was $12.7 \mu \mathrm{g} / \mathrm{ml}( \pm 0.4)$, with individual values ranging from 7.6 to $25.9 \mu \mathrm{g} / \mathrm{ml}$ (see [38]). This suggests that the proposed lower limit of normal 2-hour, post-dose concentrations of RMP is appropriate [16]. In studies of early bactericidal activity a RMP dosage of $600 \mathrm{mg}$ was more efficient at killing the metabolically active organisms present in sputum than a dosage of $300 \mathrm{mg}$, while a dosage of $150 \mathrm{mg}$ had no detectable effect $[39,40]$. The mean RMP peak serum concentration associated with a dosage of $600 \mathrm{mg}$ in early bactericidal activity studies amongst Chinese patients [39] was $9.53 \mu \mathrm{g} / \mathrm{ml}$ on the second day of treatment and amongst African patients $13 \mu \mathrm{g} / \mathrm{ml}$ and $9.5 \mu \mathrm{g} / \mathrm{ml}$ on the first and fifth days of treatment, respectively [40]. At the less efficacious dosage of $300 \mathrm{mg}$ the mean peak RMP concentration amongst Chinese patients on the second treatment day was $3.27 \mu \mathrm{g} / \mathrm{ml}$, and amongst African patients, 3.19 and $2.9 \mu \mathrm{g} / \mathrm{ml}$ and on the first and fifth treatment days, respectively.

\section{Conclusion}

This study has documented very low serum RMP concentrations in children, the great majority of whom received the often recommended standard dosage of 8 to $12 \mathrm{mg} / \mathrm{kg}$ 
body weight. While this may be of no consequence in the management of less serious forms of childhood tuberculosis, it might well be very relevant in more severe forms of tuberculosis such as are increasingly encountered in the developing world, especially in association with HIVinfection. From our data we believe that the recommended RMP dose of 10 to $20 \mathrm{mg} / \mathrm{kg}$ for children by the American Academy of Pediatrics is a more appropriate dosage range [41]. Studies of higher dosages of RMP in younger children are urgently needed to place the dosing of antituberculosis drugs in children on a more rational foundation.

\section{Abbreviations}

ALT: alanine transferase; AUC: area under the curve; BHCD: Brooklyn Hospital for Chest Diseases; CRP: Creactive protein; FDC: fixed-dose combination; HIV: human immunodeficiency virus; INH: isoniazid; RMP: rifampin; SD: standard deviation.

\section{Competing interests}

The authors declare that they have no competing interests.

\section{Authors' contributions}

PRD, HSS, DL, GDH and HM collaborated in the writing of the study protocol, KC and DL undertook the nutritional monitoring of the patients, HSS, MW, HM and PS coordinated the clinical and laboratory aspects of the study, JSM undertook the statistical analysis and PRD, HSS, DL and HM were responsible for the writing of the manuscript.

\section{Acknowledgements}

The study was supported by the BristolMyers-Squibb 'Secure the Future' Foundation. Antituberculosis drugs were supplied by Sandoz SA Pty Ltd Spartan, South Africa through normal Department of Health Government tender.

\section{References}

I. Kimmerling ME, Phillips P, Patterson P, Hall MH, Robinson CA, Dunlap NE: Low serum antimycobacterial drug levels in non-HIVinfected tuberculosis patients. Chest 1998, I I 3: I I78-I I 83.

2. Um S-W, Lee SW, Kwon SY, Yoon HI, Park KU, Song J, Lee C-T, Lee $\mathrm{J}-\mathrm{H}$ : Low serum concentrations of anti-tuberculosis drugs and determinants of their serum levels. Int J Tuberc Lung Dis 2007, I I:972-978.

3. Peloquin CA, Nitta AT, Burman WJ, Brudney KF, Miranda-Massari JR, McGuinness ME, Berning SE, Gerena GT: Low antituberculosis drug concentrations in patients with AIDS. Ann Pharmacother 1996, 30:919-925.

4. Gurumurthy P, Ramachandran G, Kumar AKH, Rajasekaran S, Padmapriyadarsini C, Swaminathan S, Bhagavathy S, Venkatesan P, Sekar L, Mahilmaran N, Paramesh P: Decreased bioavailability of rifampin and other antituberculosis drugs in patients with advanced human immunodeficiency virus disease. Antimicrob Agents Chemother 2004, 48:4473-4475.

5. Perlman DC, Segal Y, Rosenkranz S, Rainey PM, Remmel RP, Salomon $\mathrm{N}$, Hafner R, Peloquin CA: The clinical pharmacokinetics of rifampin and ethambutol in HIV-infected persons with tuberculosis. Clin Infect Dis 2005, 41:1638-1647.

6. Choudhri SH, Hawken M, Gathua S, Minyiri GO, Watkins W, Sahai J, Sitar DS, Aoki FY, Long R: Pharmacokinetics of antimycobacte- rial drugs in patients with tuberculosis, AIDS and diarrhea. Clin Infect Dis 1997, 25: 104-II I.

7. van Crevel R, Alisjahbana B, de Lange WCM, Borst F, Danusantoso $H$, Meer JWM, van der, Burger D, Nelwan RHH: Low plasma concentrations of rifampicin in tuberculosis patients in Indonesia. Int J Tuberc Lung Dis 2002, 6:497-502.

8. Tappero JW, Bradford WZ, Agerton TB, Hopewell P, Reingold AL, Lockman S, Oyewo A, Talbot EA, Kenyon TA, Moeti TL, Moffat HJ, Peloquin CA: Serum concentrations of antimycobacterial drugs in patients with pulmonary tuberculosis in Botswana. Clin Infect Dis 2005, 41:46 I-469.

9. Mcllleron H, Wash P, Burger A, Norman J, Folb PI, Smith P: Determinants of rifampin, isoniazid, pyrazinamide and ethambutol pharmacokinetics in a cohort of tuberculosis patients. Antimicrob Agents Chemother 2006, 50: I 170-I I 77.

10. Taylor B, Smith PJ: Does AIDS impair the absorption of antituberculosis agents? Int J Tuberc Lung Dis 1998, 2:670-675.

II. Jaruratanasirikul S: The pharmacokinetics of rifampicin in AIDS patients. J Med Assoc Thai 1998, 81:25-28.

12. Mcllleron H, Norman J, Kanyok TP, Fourie PB, Horton J, Smith PJ: Elevated gatifloxicin and reduced rifampicin concentration in a single-dose interaction study amongst healthy volunteers. J Antimicrob Chemother 2007, 60:1398-I40I.

13. Mascarenas MR, Zemel B, Stallings VA: Nuritional assessment in pediatrics. Nutrition 1998, 14:105-115.

14. Zemel BS, Riley EM, Stallings VA: Evaluation of methodology for nutritional assessment in children: anthropometry, body composition, and energy expenditure. Annu Rev Nutr 1997, I7:21।-235.

15. Pepys MB, Dash AC, Markham RE, Thomas HC, Williams BD, Petrie A: Comparative clinical study of protein SAP (amyloid A component) and C-reactive protein in serum. Clin Exp Immunol 1978, 32:119-124.

16. Peloquin CA: Therapeutic drug monitoring: principles and applications in mycobacterial infections. Drug Ther 1992, 22:3I-36.

17. Krauer B: The Pharmacokinetics of Rimactane in Children. Symposium on Rimactane Volume 5. Basel: Dettli L; 1968.

18. Acocella G, Buniva G, Flauto U, Nicolis FB: Absorption and elimination of the antibiotic rifampicin in newborns and children. In Proceedings of the Sixth International Congress of Chemotherapy 1969; Tokyo Volume 2. Tokyo: University of Tokyo Press; 1970:755-760.

19. Bergamini N, Matnardi L, Rosaschino F: Tassi ematici eliminazione urinaria di Rifampicina nei lattanti. Aggiorn Pediatr 1970, 21:191-197.

20. Hussels $\mathrm{H}$, Kroening $\mathrm{U}$, Magdorf $\mathrm{K}$ : Ethambutol and rifampicin serum levels in children: second report on the combined administration of ethambutol and rifampicin. Pneumonologie 1973, 149:31-38.

21. McCracken GH, Ginsburg CM, Zweighaft TC, Clahsen J: Pharmacokinetics of rifampin in infants and children: relevance to prophylaxis against Haemophilus influenzae type B disease. Pediatrics 1980, 66:17-21.

22. Tan TQ, Mason EO, Ou C-N, Kaplan SL: Use of intravenous rifampin in neonates with persistent staphylococcal bacteraemia. Antimicrob Agents Chemother 1993, 37:240I-2406.

23. Seth $\mathrm{V}$, Beotra $A$, Bagga $A$, Seth $\mathrm{S}$ : Drug therapy in malnutrition. Indian Pediatr 1992, 29: I34I-1346.

24. Seth V, Beotra A, Seth SD, Semwal OP, Kabra S, Jain Y, Mukhopadhya $S$ : Serum concentrations of rifampicin and isoniazid in tuberculosis. Indian Pediatr 1993, 30:1091-1098.

25. Mahajan M, Rohatgi D, Talwar V, Patni SK, Mahajan P, Agarwal DS: Serum and cerebrospinal fluid concentrations of rifampicin at two dose levels in children with tuberculous meningitis. Commun Dis 1997, 29:269-274.

26. World Health Organization: Treatment of tuberculosis. In Guidelines for National Programmes WHO/CDS/TB/2003.3 I 3. Geneva; 2003.

27. World Health Organization: Guidance for National Tuberculosis Programmes on the Management of Tuberculosis in Children WHO/HTM/ TB/2006.37I. Geneva; 2006.

28. Ansel HC, Stoklosa MJ: Calculation of doses. In Pharmaceutical Calculations Philadelphia, PA: Lippincott Williams \& Wilkins; 200I:63-9I.

29. Weidle PJ, Abrams EJ, Gretadze R, Rivadeneira E, Kline MW: A simplified weight-based method for pediatric drug dosing for zidovudine and didanosine in resource-limited settings. Pediatr Infect Dis J 2006, 25:59-64. 
30. American Thoracic Society/Centers for Disease Control and Prevention/Infectious Diseases Society of America: Treatment of tuberculosis. Am J Respir Crit Care Med 2003, I 67:603-662.

31. Mcllleron H, Watkins ML, Folb PI, Ress SR, Wilkinson RJ: Rifampin levels, interferon-gamma release and outcome in complicated pulmonary tuberculosis. Tuberculosis (Edinb) 2007, 87:557-564.

32. Chang KC, Leung CC, Yew WW, Kam KM, Yip CW, Ma CH, Tam CM, Leung EC, Law WS, Leung WM: Peak plasma rifampicin level in tuberculosis patients with slow culture conversion. Eur J Clin Microbiol Infect Dis 2008, 27:467-472.

33. Chang KC, Leung CC, Yew WW, Ho SC, Tam CM: A nested casecontrol study on treatment-related risk factors for early relapse of tuberculosis. Am J Respir Crit Care Med 2004, I70: II $24-1 \mid 30$.

34. Chang KC, Leung CC, Yew WW, Chan SL, Tam CM: Dosing schedules of 6-month regimens and relapse for pulmonary tuberculosis. Am J Respir Crit Care Med 2006, I 74: I I53-I I58.

35. Nahid P, Gonzalez LC, Rudoy I, de Jong BC, Unger A, Masae Kawamura L, Osmond DH, Hopewell PC, Daley CL: Treatment outcomes of patients with HIV and tuberculosis. Am J Respir Crit Care Med 2007, I 75: I I99-I206.

36. Perriëns JH, St Louis ME, Mukadi YB: Pulmonary tuberculosis in HIV-infected patients in Zaire. A controlled trial of treatment for either 6 or I 2 months. N Eng J Med I 995, 332:779-784.

37. Long MW, Snider DE, Farer LS: U.S. Public Health Service trial of three rifampin-isoniazid regimens in treatment of pulmonary tuberculosis. Am Rev Respir Dis 1979, I I 9:879-894.

38. Buniva G, Pagani V, Carozzi A: Bioavailability of rifampicin capsules. Int J Clin Pharmacol Ther Toxicol 1983, 2 I:404-409.

39. Chan SL, Yew WW, Ma WK, Girling DJ, Aber VR, Felmingham D, Allen BW, Mitchison DA: The early bactericidal activity of rifabutin measured by sputum viable counts in Hong Kong patients with pulmonary tuberculosis. Tuberc Lung Dis 1992, 73:33-38.

40. Sirgel FA, Fourie PB, Donald PR, Padayatchi N, Rustomjee R, Levin J, Roscigno G, Norman J, Mcllleron H, Mitchison DA: The early bactericidal activities of rifampin and rifapentine in pulmonary tuberculosis. Am J Respir Crit Care Med 2005, I 72: I 28-135.

41. American Academy of Pediatrics: Tuberculosis. In Red Book: 2006 Report of the Committee on Infectious Diseases 27th edition. Edited by: Pickering LK, Baker CJ, Long SS, McMilan JA. Elk Grove Village, IL: American Academy of Pediatrics; 2006:678-704.

\section{Pre-publication history}

The pre-publication history for this paper can be accessed here:

http://www.biomedcentral.com/1741-7015/7/19/prepub
Publish with Biomed Central and every scientist can read your work free of charge

"BioMed Central will be the most significant development for disseminating the results of biomedical research in our lifetime. "

Sir Paul Nurse, Cancer Research UK

Your research papers will be:

- available free of charge to the entire biomedical community

- peer reviewed and published immediately upon acceptance

- cited in PubMed and archived on PubMed Central

- yours - you keep the copyright

Submit your manuscript here:

http://www.biomedcentral.com/info/publishing_adv.asp
BiolMedcentral 